\title{
Study of Problem-based Learning and Bilingual Education Applying in Medical Informatics Course Teaching
}

\author{
Heqing Zhan* \\ College of Medical Information \\ Hainan Medical University \\ Haikou, China
}

\begin{abstract}
Medical informatics is a rapidly developing subject, while it is late started in Chinese universities as a course. This paper laid out the current teaching in medical informatics course at home and abroad, analyzed problems in course teaching, and pointed out the importance of problem-based learning (PBL) and bilingual education in medical informatics teaching. Take the teaching reform in Hainan Medical University as an example, PBL and bilingual education are integrated in the course teaching. Effects of this teaching reform have been confirmed. In this teaching mode, student's learning interest was simulated, English competence was improved, and cooperative ability was developed. The teaching quality keeps improving as a result.
\end{abstract}

Keywords-medical informatics; PBL; bilingual education; teaching reform

\section{INTRODUCTION}

Medical informatics is a new developing cross subject. It aims to utilize information science and technology in the field of medicine and extract effective information from the medical big data to improve medical decision and management. Due to the late starting of medical informatics course in universities and the lack of creation of this course in medical colleges in China, medical informatics teaching faces many problems and difficulties, such as single teaching mode, outmoded teaching contents and different levels in students, which hurt the teaching results.

Based on the above problems, we provided some effective measures to promote the teaching reform. We integrated PBL and bilingual education into medical informatics teaching. PBL changed the teaching mode from traditional cramming to interactive teaching. On the other hand, bilingual education helped students understand technical terms in medical informatics and develop the habit of thinking in English. These methods stimulated students' interest and encouraged them to take ownership of their learning.

\section{ANALYSIS OF MEDICAL INFORMATICS TEACHING AT HOME AND ABROAD}

\section{A. Medical Informatics Teaching in China}

The medical informatics course got a slow start and imperfect development in our country. In the 1980s, the

Sponsored by the Educational Research Project of Hainan Medical University education of library and information science has been started in four universities. Since the definition of medical informatics remained unclear before the $21^{\text {st }}$ century, it has not been set up as a course in colleges. In the new century, the hospital information construction has been constantly improved with the development of computer science and network technology. The demand for interdisciplinary talents has been increasing as a result, which promoted universities to set up the medical informatics major. By 2018, the number of universities established the major was nearly 40 [1].

The content of medical informatics subject is abundant and extensive. Therefore, universities have their own emphasis on choosing teaching content. For science and engineering universities, they integrated medical informatics with biomedical engineering and instrument science and technology, and the teaching content was focused on the application of computer and technology science in the medical field as a result. For medical universities, the course was derived from library and information subject, and the teaching content was focused on medical information retrieval and management [2]. In general, the key issues, such as how to utilize informatics to improve medical data mining and analysis, and to improve students' perception and thinking, are still needed to be noticed.

\section{B. Medical Informatics Teaching in Europe and America}

The medical informatics course was established earlier in developed countries. Some of them first taught this class was back in 1960s. This subject has grown dramatically in recent decades, and has already formed a complete system. These universities advanced the training objectives of medical informatics course that medical informatics teaching should focus on the unity of information science and medicine to promote the development of the healthcare industry with information technology [3].

\section{PROBlEMS IN MEDICAL INFORMATICS TEACHING IN CHINA}

Medical informatics is a highly cross disciplinary, which mixes medicine, computer science and information technology together. It studies the life and medical information in human society. The aim of the subject is to share and utilize medical information with medical data processing, and finally, to raise 
the efficiency in medical decision-making. According to the consideration of "what the course content demands from teaching" and analysis of current teaching mode, we summarized the problems existing in the course teaching in our country.

\section{A. The Single Mode of Teaching}

The traditional mode of medical informatics course teaching is comprised of theory teaching and practical teaching. Hours of theory lessons are far more than that of practical lessons. The so-called practice is mainly on computer training. Some medical colleges even left all hours to theory class, while none to practice. In recent years, the colleges have been implementing reforms of medical informatics course teaching mode gradually, such as E-learning. But the reforms were still in exploring and discussing, and have not yet been implemented into the actual teaching work [4].

The mode in theory teaching is also boring. Teachers prefer to keep using the traditional mode that mainly on force-feeding teaching and supplemented by passive learning. However, choosing the above mode usually make the teaching become a one-man show for teachers. This is embarrassing. For students, their interests are hard to be stimulated in passive learning. Knowledge is easily forgotten because they did not participate in their own learning.

\section{B. The Single Language in Teaching}

Medical informatics lays out the source and structure of medical information, and the ways it propels medicine more forward. The course is aimed at cultivating student's perception and thinking to information, and to lead students to meet the demands in the information age. At present, this discipline is changing with each passing day, and its cutting-edge research is all around the world. Most of the products, which were accepted in leading journals and works, were written in English [5]. Besides, the graduates have to use English inevitably in their future study and work which are relevant about the products. However, many universities have no choice but to teach in Chinese due to the different English levels of students. The Chinese teaching facilitated study, yet made students miss their chances of understanding the ways of English express and thinking in medical informatics.

\section{The Invariable Content in Teaching}

With the late starting of medical informatics teaching in our country, the teaching content is deficient. It is hard to keep up with the quick growth in this subject. The content which universities chose to teach mainly depended on published textbooks. Once the books were adopted, they remained for a number of years. This is most likely to lead to an invariable content.

\section{THE IMPORTANCE OF PBL AND BILINGUAL EDUCATION DURING MEDICAL INFORMATICS TEACHING}

\section{A. $P B L$}

Problem-based learning (PBL) was an impressive innovation in foreign education, which was first applied in
America [6]. The mode of PBL was problem-centered and students-oriented. Teachers raised a question and then students thought about it and had a discussion. Instead of being proposed directly, the question was usually designed in a special scenario. Teachers should note that they are guiding the discussion rather than leading it. Students were problem solvers. They considered the problem, looked up the authoritative source and joined the conversation. In this process, their interests were inspired and the knowledge in the course content was understood. PBL could help students improve their ability of active learning and collaborative learning, as well as skills in practices and problem solves [7].

The course of medical informatics is a core curriculum that develops the information literacy of students. By learning the curriculum, students could understand the fundamentals of medical informatics, know the whole idea of it, and finally gain a general cognition about the field. Graduates mastered the methods of medical information collection, management and application to lay a ground work for their future work and research in the domain of healthcare information.

So essentially, the teaching objectives of the medical informatics course are in conformance with that in PBL. PBL mode is very necessary for students to cultivate the capacity to study.

\section{B. Bilingual Education}

According to Longman dictionary of applied linguistics, bilingual education was interpreted as the use of a second or foreign language in school for the teaching of content subjects [8]. In our universities, the core of bilingual education is as follows.

1) Take English as a second teaching language and use it partially or fully in non-linguistic disciplines teaching, such as natural sciences and social sciences, to spread knowledge in students.

2) Take English as a learning object. In this case, English is combined with majors. It became a special course which contains professional vocabulary about these majors.

Medical informatics is the bridge between medicine and informatics. Students will benefit from the systematic study of this course. It provides significant theoretical basis for healthcare information management, and is going to be instructive to look at medical information process. Bilingual education is extraordinarily useful and constructive, not only for getting the processes and updates in medical informatics, but also for keeping the teaching content up-to-date with subject development. With the organization and development of bilingual education, students could master professional knowledge and skills for medical information management, and improve their work capability and creativity.

\section{INSTRUCTIONAL DESIGN}

\section{A. Arrangement for Teaching Content}

The teaching content of medical informatics course is comprised of the basic concept and fundamentals, research contents and developments in this field. Take the teaching 
reform in Hainan Medical University as an example, the content and periods assignment of this course were listed in TABLE I.

TABLE I. TEACHING CONTENT AND PERIODS AssignMENT OF MEDICAL INFORMATICS COURSE IN HAINAN MEDICAL UNIVERSITY

\begin{tabular}{|c|c|c|}
\hline \multirow{2}{*}{ Teaching Content } & \multicolumn{2}{|c|}{ Periods } \\
\hline & Theory & PBL \\
\hline Introduction of Medical Informatics & 2 & \\
\hline Medical Big Data and Cloud Computing & 4 & \\
\hline $\begin{array}{l}\text { Computer Architecture and Software Engineering in } \\
\text { Medical Information Management }\end{array}$ & 4 & \\
\hline Standards in Medical Informatics & 2 & \\
\hline Smart Healthcare & 6 & 2 \\
\hline $\begin{array}{l}\text { Electronic Medical Records and Clinical Decision } \\
\text { Support System }\end{array}$ & 8 & 2 \\
\hline Patient-oriented Nursing Information System & 2 & \\
\hline Patient Monitoring System & 2 & \\
\hline $\begin{array}{l}\text { Biomedical Imaging Informatics and Imaging } \\
\text { Systems in Radiology }\end{array}$ & 6 & \\
\hline Telemedicine & 3 & \\
\hline Community Health Information System & 3 & \\
\hline Public Health Information System & 4 & 2 \\
\hline $\begin{array}{l}\text { Consumer Health Informatics and Personal Health } \\
\text { Records }\end{array}$ & 4 & \\
\hline Bioinformatics and Translational Bioinformatics & 4 & \\
\hline Total & 0 & \\
\hline
\end{tabular}

\section{B. Arrangement for $P B L$}

\section{1) The Section of Problem design and introduction}

The questions need to be introduced skillfully. Teachers created scenarios that made students all feel involved, and then the questions, according to the course content and reflecting the cutting-edge development, were introduced. Students were actively engaged in thinking and discussing, and therefore, were generally impressed by the content. The problems can be designed as follows.

Since electronic medical records (EMRs) are a very important part of telemedicine, how would you describe the relationship between EMRs and telemedicine? How to build a multifunctional EMR system in telemedicine? Will the information implied in DNA or protein sequences change the ways of medical record management in the future? If this happens, which medical information system (the laboratory information system, radiology information system, financial information system and so on) would be most affected by this change?

\section{2) The Section of PBL discussion}

When the problem was introduced, students began to think about it, looked up sources online, talked with their partner or other group members and finished their report together. During their lectures, teachers discussed the research background, progress, problems and solutions in studies at home and abroad with students, to help them understand the knowledge hidden behind the question.

\section{Introduce Bilingual Education Step by Step}

Due to the different English levels of students, bilingual education should be introduced step by step. At the beginning, teachers should consider which part is appropriate for students to learn in bilingual forms. At first, it maybe two or three chapters, and then more chapters, finally the whole text. Step by step means the bilingual content was from the shallower to the deeper, to adapt to students levels.

\section{Course Assessment}

The final grade of this course is composed of three parts: attendance $10 \%$, PBL reports and discussion 30\%, final exam $60 \%$. In this way, students learning outcomes are evaluated comprehensively.

\section{PRELIMINARY RESULTS}

We did a questionnaire survey of 200 students who have learned the course. $75 \%$ of them recognized the teaching effect of PBL and bilingual education. 'Our learning interest was indeed simulated and English competence was improved in this mode, all whilst developing our cooperative ability,' they said. The other 25\% wrote down their issues in the questionnaire, such as too little PBL hours, heavy learning loads, poor English expression and so on.

\section{CONCLUSION}

The integration of PBL and bilingual education with medical informatics course has increased students' study passion, and made them innovative and collaborative. During the exploration in PBL and bilingual education in medical informatics teaching, teachers could improve their teaching levels. This pushes the teaching reform of medical informatics to keep moving forward, and the teaching quality is constantly improving.

\section{ACKNOWLEDGMENT}

This project is supported by the Educational Research Project of Hainan Medical University (HYP201705).

\section{REFERENCES}

[1] Yuanpeng Zhang, Jianmei Sheng, Kui Jiang, Li Wang, Yalan Chen and Jiancheng Dong, "Comparative Study on Medical Informatics Education between China and Europe,” Chinese Journal of Library and Information Science for Traditional Chinese Medicine, vol. 39, pp. 32-36, October 2015. (In Chinese)

[2] Zhihui Huang, "Study of Innovative Teaching Mode of Medical Informatics Course in Colleges and Universities of Traditional Chinese Medicine,” Health Vocational Education, vol. 34, pp. 1-2, 2016. (In Chinese)

[3] Cheng Qian, Xiaobin Chu, Jinyan He, Li Ge and Huizhen Lu, "Enlightenment of Medical Informatics Curriculum Reform of Oregon Health and Science University in the USA," Journal of Medical Informatics, vol. 36, pp. 8-11, 2015. (In Chinese)

[4] Xuefang Mei, and Hongxin Cao, "Study on reform of medical informatics teaching model," Chinese Journal of Medical Education, vol. 33, pp. 693-695, October 2013. (In Chinese)

[5] Chuan Lin, "Bilingual Teaching of the Medical Literature Retrieval Course,” Journal of Medical Informatics, vol. 3, pp. 68-71, 2008. (In Chinese)

[6] HS Barrows, and RM Tamblyn, “The portable patient problem pack: a problem-based learning unit,” Journal of Medical Education, vol. 52, pp. 1002-1004, 1977. 
[7] Hong Zhao, "Practice of the PBL Teaching Mode in the Medical Information Retrieval Course for Graduate Students,” Journal of Medical Informatics, vol. 36, pp. 91-94, 2015. (In Chinese)
[8] Xia Li, Kaiyu Tong, Chuanyu Zhang, and Xiaofeng Chen, "Some Features of Bilingual Teaching in Chinese Universities,” Education Teaching Forum, No. 51, pp. 221-222, 2016. (In Chinese) 